\title{
Effects of WhatsApp Based Online Learning to Students' Satisfaction during COVID-19 Mitigation in Rural Area of Indonesia
}

\author{
Dwi Sulisworo ${ }^{1, *}$, Muh. Amiruddin Salem ${ }^{2}$, Rahmad Bala ${ }^{2}$, Ma'ruf Ishak Ola $^{2}$ \\ ${ }^{1}$ Physics Education Department, Faculty of Teacher Training and Education, Universitas Ahmad Dahlan, Indonesia \\ ${ }^{2}$ Tarbiyah Department, Sekolah Tinggi Agama Islam Kupang, Indonesia
}

Received December 13, 2020; Revised January 21, 2021; Accepted February 18, 2021

\section{Cite This Paper in the following Citation Styles}

(a): [1] Dwi Sulisworo, Muh. Amiruddin Salem, Rahmad Bala, Ma'ruf Ishak Ola, "Effects of WhatsApp Based Online Learning to Students' Satisfaction during COVID-19 Mitigation in Rural Area of Indonesia," Universal Journal of Educational Research, Vol. 9, No. 2, pp. 299 - 309, 2021. DOI: 10.13189/ujer.2021.090206.

(b): Dwi Sulisworo, Muh. Amiruddin Salem, Rahmad Bala, Ma'ruf Ishak Ola (2021). Effects of WhatsApp Based Online Learning to Students' Satisfaction during COVID-19 Mitigation in Rural Area of Indonesia. Universal Journal of Educational Research, 9(2), 299 - 309. DOI: 10.13189/ujer.2021.090206.

Copyright $(2021$ by authors, all rights reserved. Authors agree that this article remains permanently open access under the terms of the Creative Commons Attribution License 4.0 International License

\begin{abstract}
Covid-19 pandemic has a significant impact on learning practices in various countries. The Government of Indonesia conducts Covid-19 Mitigation in various sectors, including education. MOEC (Ministry of Education and Culture) issued regulations to organize knowledge using online learning at all levels of schools in all regions. Elementary schools in rural areas face obstacles in implementing online learning according to government regulations during the pandemic. Teachers use a variety of applications when carrying out online learning. Teachers use social media applications the most in education during this rapid change situation. One of the social media used during this mitigation is WhatsApp. This study aims to describe the response of learner's satisfaction in Nusa Tenggara Timur, Indonesia, during online learning with this media. This research is a quantitative descriptive study using the COLLES questionnaire. This questionnaire was created using Google Form and distributed through WhatsApp Group to students. The sampling technique used was the purposive sampling of 123 students who joined online lectures using this media. The results of this study show that students are generally satisfied with online learning. Some aspects that need to be improved are at the level of appreciation, lecturer feedback during lectures. These results provide optimism for online learning as a new learning process in the modern era after Covid-19 mitigation ends.
\end{abstract}

Keywords COVID-19, COLLES Questionnaire, Education Equity, Learner's Satisfaction, Online Learning, Rural Area, WhatsApp

\section{Introduction}

The emergence of the Covid-19 pandemic has an impact on various aspects of life. The spread of the COVID-19 coronavirus happens in all nations. This pandemic occurrence has been paid attention by different segments remembering for the universe of training. Various countries have chosen to decide to close schools and universities $[1,2]$. The crisis comes to fruition; the difficulty policymakers are looking between closing schools and keeping them open [3,4]. Indonesia, as a nation with a significant populace, has given different approaches concerning learning. All schools in Indonesia are urged to actualize separation learning by using data innovation. There are numerous open reactions to this strategy, and all in all, all gatherings concur. The fundamental obstruction to the usage of this learning model is the accessibility of offices and foundation in a few zones. The influence of the pandemic affected the change in lecture methods for students in Nusa Tenggara Timur, from conventional to online-based learning. The lecture process at various colleges in Nusa Tenggara 
Timur must be ready to adapt to changing times for the sake of effective and efficient lectures. The online lecture policy is in the Minister of Education and Culture (MOEC) Circular Letter Number: 36962 / MPK.A / HK / 2020 concerning Online Learning and Working from Home in the Context of Preventing Corona Virus Disease (Covid-19) [5].

The use of online-based learning technology has effectiveness and efficiency in improving the quality of learning, increasing interest [6], learning motivation, and learning achievements [7]. However, in this sudden online learning, teachers, and students need to make technical adjustments and will encounter several obstacles in several aspects $[8,9]$. The advantage in this situation is that students come from millennial groups who have functional information technology literacy as supporters of online learning $[10,11]$. The results of previous studies show that the use of WhatsApp is not only in social media interactions, but teachers can also use it as a medium for learning interactions. Teachers can develop the activities with the media such as material explanation, discussion, material delivery, and task collection. The use of this media also allows more flexible learning both in terms of time and place [12]. The features in this application that allow for the development of a conducive online learning environment such as Gallery (picture management), Contact (member management), Camera (picture or video sharing), Audio (voice sharing), Maps (position sharing), Document (file sharing). The wise use of these features allows an increase in social presence during learning.

Minister of Education and Culture's policy regarding the implementation of online learning above also impacts the lecture process at Higher Education in Nusa Tenggara Timur. Most lecturers use WhatsApp to support the lecture process, both as a means of online discussion, sharing material, as well as giving assignments and sending assignments. The learning process in various colleges in Nusa Tenggara Timur experienced rapid changes due to the Covid-19 pandemic. In these situations, lecturers must be able to design active online learning by utilizing appropriate learning media and following the material. The results of a short interview with several lecturers in Nusa Tenggara Timur (NTT) stated that the most widely used online learning media is WhatsApp application because the operation is straightforward and easily accessible to students. The lecturers, as facilitators, need creativity in applying models and various learning strategies that enable the lecture process to work well.

An essential aspect of finding out is what perceptions or beliefs students have in using this technology in teaching and learning activities [13-16]. In addition to student confidence, the availability of supporting facilities for the implementation of digital technology-based learning is critical [17-19]. During the Covid-19 mitigation period, online learning was organized by campuses in Nusa Tenggara Timur. With the limitations of the internet infrastructure, internet data owned by students, the level of literacy in the use of standard LMS (e.g., Moodle), many campuses tend to choose WhatsApp as a medium for the implementation of online lectures. For online learning sustainability, it is necessary to examine the impact of using this media in learning various aspects of the learning quality. One of the questionnaires to measure the effects is by Colles Questionaire. This questionnaire is a standard questionnaire that uses a constructivist learning approach. Based on these opportunities, this study seeks to uncover and explain the online learning process with WhatsApp and the impact of learning satisfaction felt by students. Education managers can utilize the study results to improve the quality of learning by the characteristics of students and the availability of educational resources in certain areas.

\section{Methods}

\subsection{Research Design}

This type of research is survey research on students in all tertiary institutions in Nusa Tenggara Timur province, Indonesia, carried out during the Covid-19 mitigation period from April 1 to May 20, 2020. The locations of this study were 16 colleges in Nusa Tenggara Timur. This region is one area in Indonesia where the community's economic level is middle to lower class. In general, the colleges in this region have internet access through Telkomsel providers. The sample of this study was students who took online lectures using WhatsApp.

Table 1. The Arrangement of Channels

\begin{tabular}{|c|c|c|}
\hline \multicolumn{2}{|c|}{ Variables/ Factors } & $\mathrm{N}$ \\
\hline \multirow{2}{*}{ Gender } & Male & 44 \\
\hline & Female & 65 \\
\hline \multirow{9}{*}{ Duration of Study/ Semester } & $2^{\text {nd }}$ & 29 \\
\hline & $4^{\text {th }}$ & 32 \\
\hline & $5^{\text {th }}$ & 2 \\
\hline & $6^{\text {th }}$ & 25 \\
\hline & $7^{\text {th }}$ & 1 \\
\hline & $8^{\text {th }}$ & 14 \\
\hline & $10^{\text {th }}$ & 3 \\
\hline & $12^{\text {th }}$ & 2 \\
\hline & $14^{\text {th }}$ & 1 \\
\hline \multirow{6}{*}{ Field of Study } & Islamic Studies & 51 \\
\hline & Engineering and Technology & 13 \\
\hline & STEM Education & 12 \\
\hline & Economics \& Business & 8 \\
\hline & Humanities & 4 \\
\hline & Social Education & 21 \\
\hline \multirow{3}{*}{ Social Media Experience } & Less than 5 years & 81 \\
\hline & 5 to 10 years & 21 \\
\hline & More than 10 years & 7 \\
\hline
\end{tabular}

The sampling technique was purposive sampling to 
collect the participants, and they filled the COLLES questionnaire through WhatsApp lectures. The number of students who filled responses was 123 students. However, there were invalid data due to incomplete filling of the survey (1), extremely low (2) or high (11)), so that the data processed were 109 respondents. See Table 1.

The COLLES measure students' perceptions of both their preferred and actual online learning environments. This survey covers Relevance (4), Reflection (4), Interactivity (4), Tutor Support (4), Peer Support (4), and
Interpretation (4) factors. The questionnaire was made with Google Form with a Likert scale: Almost Never (1), Seldom (2), Sometimes (3), Often (4), Almost Always (5).

The data processing used descriptive statistical analysis and Two-way ANOVA. The independent variables of this study were: gender (IDVAR1), duration of the study (IDVAR2), the field of study (IDVAR3), WhatsApp experience (IDVAR4). The independent variable was the students' responses to online learning (DVAR). Table 2 shows the questionnaire items.

Table 2. The Arrangement of Channels

\begin{tabular}{|c|c|c|}
\hline \multicolumn{2}{|r|}{ Factor and Items } & Item Code \\
\hline \multicolumn{3}{|c|}{ Relevance: the course's relevance to student's interests and professional goals } \\
\hline 1. & my learning focuses on issues that interest me. & REL1 \\
\hline 2. & what I learn is important for my professional practice. & REL2 \\
\hline 3. & I learn how to improve my professional practice. & REL3 \\
\hline 4. & what I learn connects well with my professional practice. & REL4 \\
\hline \multicolumn{3}{|c|}{ Reflective thinking: the level of critical or reflective thinking that the student applies to the material in the course } \\
\hline 5. & I think critically about how I learn. & REF1 \\
\hline 6. & I think critically about my own ideas. & REF2 \\
\hline 7. & I think critically about other students' ideas. & REF3 \\
\hline 8. & I think critically about ideas in the readings. & REF4 \\
\hline \multicolumn{3}{|c|}{ Interactivity: the level of interactivity the student engages in during the course } \\
\hline 9. & I explain my ideas to other students. & INT1 \\
\hline 10. & I ask other students to explain their ideas. & INT2 \\
\hline 11. & other students ask me to explain my ideas. & INT3 \\
\hline 12. & other students respond to my ideas. & INT4 \\
\hline \multicolumn{3}{|c|}{ Tutor Support: the level of tutor support } \\
\hline 13. & the tutor stimulates my thinking. & TUT1 \\
\hline 14. & the tutor encourages me to participate. & TUT2 \\
\hline 15. & the tutor models good discourse. & TUT3 \\
\hline 16. & the tutor models critical self-reflection. & TUT4 \\
\hline \multicolumn{3}{|c|}{ Peer Support: the student is receiving peer support in the course } \\
\hline 17. & other students encourage my participation. & PEE1 \\
\hline 18. & other students praise my contribution. & PEE2 \\
\hline 19. & other students value my contribution. & PEE3 \\
\hline 20. & other students empathize with my struggle to learn. & PEE4 \\
\hline \multicolumn{3}{|c|}{ Interpretation: the success of both students and tutor in making good sense of each other's communication } \\
\hline 21. & I make a good sense of other students' messages. & INP1 \\
\hline 22. & other students make a good sense of my messages. & INP2 \\
\hline 23. & I make a good sense of the tutor's messages. & INP3 \\
\hline 24. & the tutor makes a good sense of my messages. & INP4 \\
\hline
\end{tabular}




\subsection{Learning Strategy}

Lecturers implemented WhatsApp-based online learning strategies in NTT. In general, the stages of learning are like Figure 1. These stages include the following activities.

1. The lecturer created a WhatsApp group. Through this group, lecturers managed learning, which facilitated interaction between lecturers, students, and students.

2. At the beginning of each meeting, the lecturer ensured the students' presence and readiness to attend lectures. At this stage, the lecturer orientated students' learning process.

3. There were specific topics discussed at each meeting. Lecturers provide a variety of learning resources both in the form of plain-text, attachment documents (DOC, PPT, PDF, Video, Picture, Voice), and links to support well lectures. The students could download these documents.

4. The lecturers used the method of discussion in learning interactions. They gave discussion topics to students. Each student got one problem as well as acting as a speaker and guided the discussion. At this stage, a question-and-answer process occurred among students. The lecturer gave comments in the form of direction, improvement and feedback, appreciation in the form of words and emoticons.

5. Lecturers provided time-limited quizzes, thus requiring students to be active in online lectures based on a predetermined time. For students who answered beyond the allotted time, they did not get a quiz score.

6. As a reinforcement of online learning activities, lecturers gave structured assignments by making a resume or short opinion.
7. Based on all learning activities, lecturers provided feedback and evaluated the learning process. Lectures can apply these results improvement in the next learning.

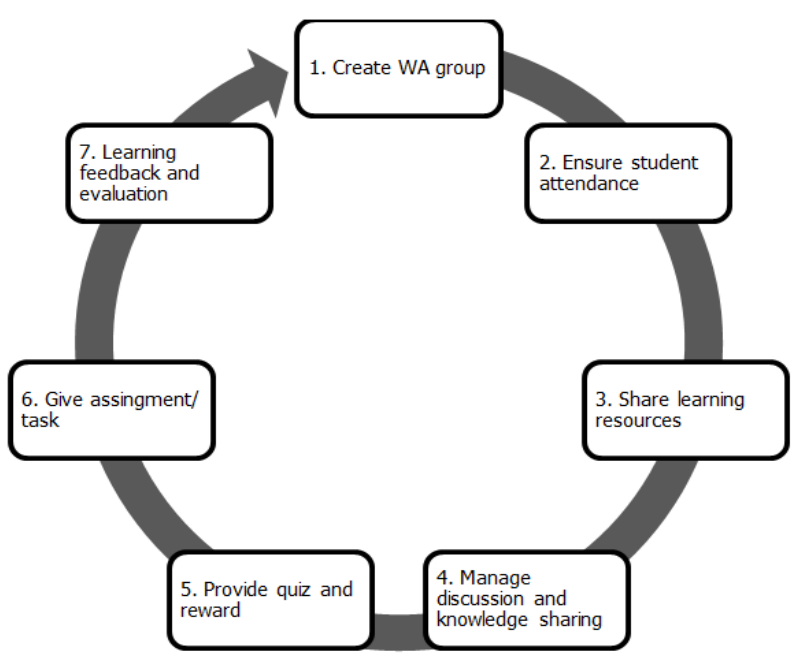

Figure 1. The learning process

\section{Result}

\subsection{Descriptive Analysis}

The descriptive analysis is based on the response of each item seen from the frequency, mean, standard deviation, minimum and maximum scores. Table 3 shows the results of processing these responses.

Table 3. The result of the COLLES survey

\begin{tabular}{|c|c|c|c|c|c|c|c|c|c|}
\hline \multirow{2}{*}{ Items } & \multicolumn{5}{|c|}{ Scale/ Frequency $(\mathrm{N}=109)$} & \multirow{2}{*}{ Mean } & \multirow{2}{*}{ STD } & \multirow{2}{*}{ Min } & \multirow{2}{*}{$\operatorname{Max}$} \\
\hline & 1 & 2 & 3 & 4 & 5 & & & & \\
\hline REL1 & 13 & 7 & 36 & 22 & 31 & 3.47 & 1.30 & 1 & 5 \\
\hline REL2 & 4 & 0 & 14 & 18 & 73 & 4.43 & 0.98 & 1 & 5 \\
\hline REL3 & 4 & 4 & 17 & 23 & 61 & 4.22 & 1.07 & 1 & 5 \\
\hline REL4 & 2 & 10 & 18 & 26 & 53 & 4.08 & 1.09 & 1 & 5 \\
\hline REF1 & 1 & 6 & 22 & 26 & 54 & 4.16 & 0.99 & 1 & 5 \\
\hline REF2 & 2 & 3 & 15 & 22 & 67 & 4.37 & 0.95 & 1 & 5 \\
\hline REF3 & 6 & 13 & 34 & 21 & 35 & 3.61 & 1.21 & 1 & 5 \\
\hline REF4 & 3 & 4 & 28 & 26 & 48 & 4.03 & 1.05 & 1 & 5 \\
\hline INT1 & 7 & 6 & 35 & 32 & 29 & 3.64 & 1.13 & 1 & 5 \\
\hline INT2 & 5 & 6 & 36 & 37 & 25 & 3.65 & 1.04 & 1 & 5 \\
\hline INT3 & 4 & 9 & 42 & 26 & 28 & 3.60 & 1.07 & 1 & 5 \\
\hline INT4 & 4 & 6 & 37 & 35 & 27 & 3.69 & 1.02 & 1 & 5 \\
\hline TUT1 & 7 & 12 & 28 & 29 & 33 & 3.63 & 1.21 & 1 & 5 \\
\hline TUT2 & 6 & 7 & 22 & 27 & 47 & 3.94 & 1.18 & 1 & 5 \\
\hline TUT3 & 7 & 6 & 27 & 24 & 45 & 3.86 & 1.21 & 1 & 5 \\
\hline TUT4 & 7 & 9 & 24 & 25 & 44 & 3.83 & 1.23 & 1 & 5 \\
\hline PEE1 & 9 & 6 & 23 & 32 & 39 & 3.79 & 1.23 & 1 & 5 \\
\hline PEE2 & 10 & 10 & 27 & 37 & 25 & 3.52 & 1.21 & 1 & 5 \\
\hline PEE3 & 3 & 8 & 21 & 40 & 37 & 3.92 & 1.04 & 1 & 5 \\
\hline PEE4 & 5 & 6 & 25 & 40 & 33 & 3.83 & 1.07 & 1 & 5 \\
\hline INP1 & 3 & 3 & 34 & 41 & 28 & 3.81 & 0.95 & 1 & 5 \\
\hline INP2 & 2 & 7 & 32 & 41 & 27 & 3.77 & 0.96 & 1 & 5 \\
\hline INP3 & 3 & 3 & 27 & 39 & 37 & 3.95 & 0.98 & 1 & 5 \\
\hline INP4 & 0 & 7 & 29 & 44 & 29 & 3.87 & 0.88 & 2 & 5 \\
\hline
\end{tabular}


From the frequency column, it appears that there is a tendency for respondents to respond predominantly to scores 3,4 , and 5 on all items. So it can be seen that the average rating is more than 3.00 in all items.

\subsection{Two-Way ANOVA}

This analysis is applied to see the effect of IDVAR1, IDVAR2, IDVAR3, and IDVAR on DVAR. Table 4shows the results of this analysis.
From Table 4 (red box), there are no independent variables that affect DVAR ( $p$-value $=0.05$ ). Although there are no independent variables that affect student satisfaction response, the value of R-Squared (.598) shows that this model is good enough to explain the phenomenon of the extent of online learning with WhatsApp (59.8\%). Further analysis is to look at the interaction between independent variables. Figure 2 and Figure 3 show this result.

Table 4. Tests of Between-Subjects Effects

Dependent Variable: AVG_SCORE

\begin{tabular}{|c|c|c|c|c|c|}
\hline Source & $\begin{array}{l}\text { Type III Sum of } \\
\text { Squares }\end{array}$ & Df & Mean Square & $\mathbf{F}$ & Sig. \\
\hline Corrected Model & $33.014^{\mathrm{a}}$ & 53 & .623 & 1.542 & .057 \\
\hline Intercept & 439.934 & 1 & 439.934 & 1089.127 & .000 \\
\hline IDVAR1 & .650 & 1 & .650 & 1.610 & .210 \\
\hline IDVAR2 & 3.388 & 8 & .424 & 1.049 & .412 \\
\hline IDVAR3 & 3.436 & 5 & .687 & 1.702 & .150 \\
\hline IDVAR4 & 2.134 & 2 & 1.067 & 2.642 & .080 \\
\hline IDVAR $1 *$ IDVAR2 & .718 & 3 & .239 & .592 & .623 \\
\hline IDVAR1 $*$ IDVAR3 & 1.889 & 3 & .630 & 1.559 & .210 \\
\hline IDVAR $1 *$ IDVAR 4 & 2.263 & 2 & 1.131 & 2.801 & .069 \\
\hline IDVAR2 $*$ IDVAR3 & 2.700 & 9 & .300 & .743 & .668 \\
\hline IDVAR2 $*$ IDVAR 4 & 1.010 & 4 & .253 & .625 & .646 \\
\hline IDVAR3 $*$ IDVAR4 & 3.089 & 3 & 1.030 & 2.549 & .065 \\
\hline IDVAR $1 *$ IDVAR $2 *$ IDVAR3 & .102 & 2 & .051 & .126 & .882 \\
\hline IDVAR $1 *$ IDVAR $2 *$ IDVAR 4 & .000 & 0 & . & . & . \\
\hline IDVAR1 * IDVAR3 * IDVAR4 & 2.268 & 1 & 2.268 & 5.615 & .021 \\
\hline IDVAR2 $*$ IDVAR3 $*$ IDVAR4 & .000 & 0 & . & . & . \\
\hline $\begin{array}{l}\text { IDVAR } 1 * \text { IDVAR2 } * \text { IDVAR3 } * \\
\text { IDVAR4 }\end{array}$ & .000 & 0 & . & . & . \\
\hline Error & 22.216 & 55 & .404 & & \\
\hline Total & 1679.686 & 109 & & & \\
\hline Corrected Total & 55.230 & 108 & & & \\
\hline
\end{tabular}

a. R Squared $=.598($ Adjusted R Squared $=.210)$ 
Estimated Marginal Means of DVAR

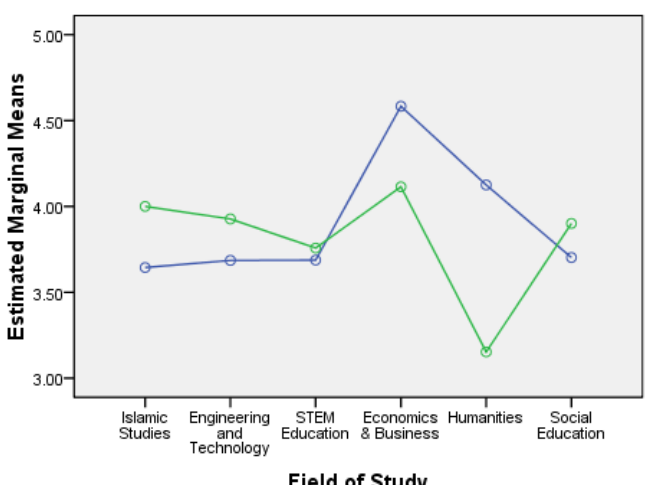

Figure 2. Interaction between gender and field of study

Figure 2 shows the interaction between the Field of Study (IDVAR3) and Gender (IDVAR1). There is an interaction between IDVAR3 and IDVAR1. In specific Fields of Study, male students have lower DVAR scores than female students.

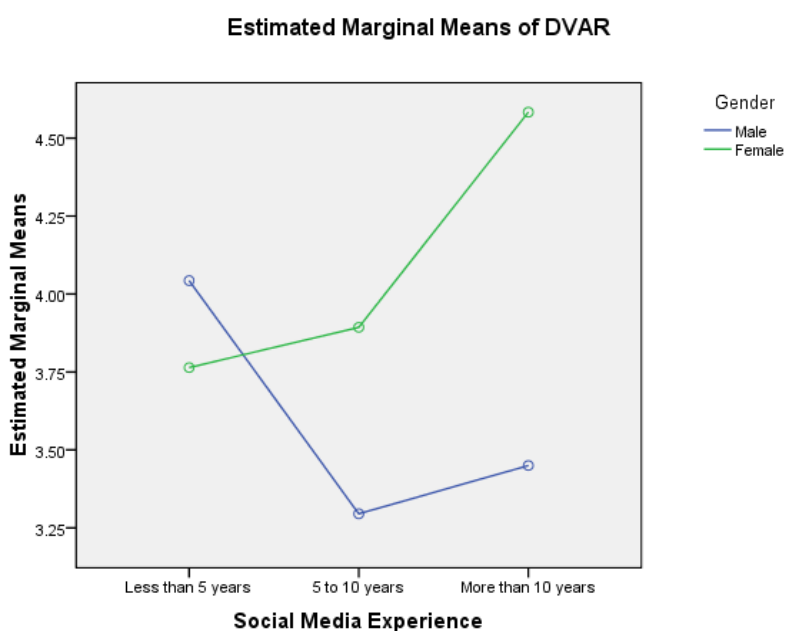

Figure 3. Interaction between gender and social media experience

Whereas Figure 3 shows the interaction between Social Media Experience (IDVAR4) and Gender (IDVAR1). There is an interaction between IDVAR4 and IDVAR1. For social media users less than 5 years old, the DVAR score for males is higher than that of females. Conversely, in older users, female users had higher DVAR scores than male users.

\section{Discussions}

\subsection{Learning Response}

Table 3 can be converted to Figure 4 for the typical diagram of each COLLES score. Figure 4 explains how the scores of each item are distributed. Figure 4 shows the average score for each item of relevance aspects (REL1, REL2, REL3, REL4). From this figure, only REL1 scores lower than 4.00. There is a strong tendency for teacher responses to frequent and almost always responses to all items. This result implies that there is a tendency that online learning is very relevant to the learning needs of students. The perception of learning experiences in pertinent aspects that get high scores becomes the hope that online learning fits into the real world they will face. The tendency that young students and digital natives make them feel comfortable with learning done.

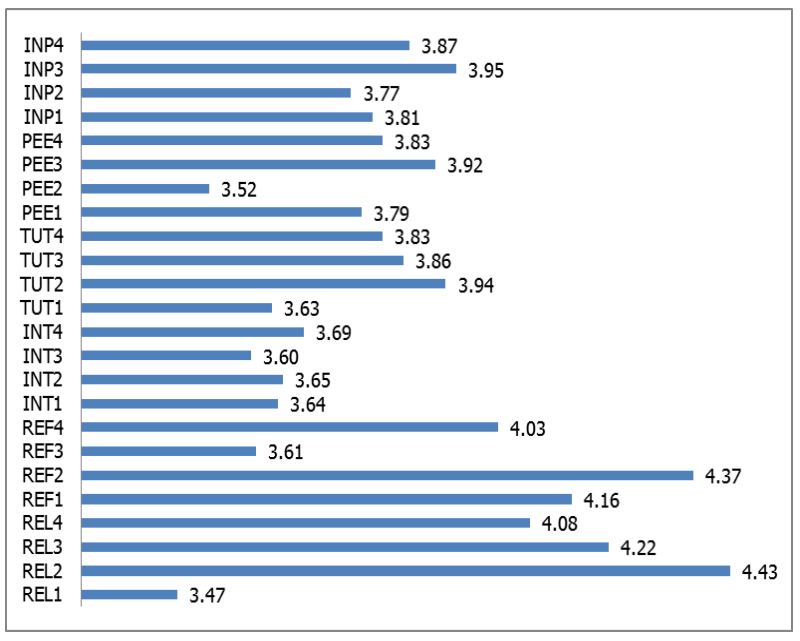

Figure 4. Students' response to each factor

Figure 4 shows the aspects of reflective thinking (REF1, REF2, REF3, REF4) that measure the level of critical thinking applied in lectures. In this aspect, almost all of them gave responses above 3 . From the results of the students' responses, the learning went well to support the development of reflective/critical thinking. Students can develop the ability to reflect on what they are learning, individual ideas, ideas from other participants, and ideas from available reading. The development of critical thinking skills can occur when someone is dealing with an ill-defined problem. This situation in lectures often arises when there is a discussion between participants and the difficulties the lecturer raises. Learning in the current era requires the achievement of competencies for solving skill problems. Lecture activities that have rarely used open-ended questions (ill-defined problems) make students still need to be encouraged to express their ideas more comfortably. Students can achieve this condition if other aspects, such as the support of lecturers and other students.

The interactivity aspect (INT1, INT2, INT3, INT4) measures the level of interactivity of the students involved during the lecture. Figure 4 shows that this aspect is the aspect with the lowest response compared to the others. Although overall, it is relatively good (above 3.00 ). The habit of participants who will not present ideas unless stimulated externally makes posting in forums and chatting is not high enough. From the pattern of posting activities, participants would respond to the discussion if 
they are asked by the lecturer to respond. This fact shows that there are sub-optimal interactions between students. This situation is also seen in the low desire of other students to utter ideas. There is a tendency for students to respond to requests from lecturers only, but not to respond to requests from fellow students. This finding is a special note that needs attention. Many other studies that show intense interaction in online learning represents a high social presence. Learning in lower schools that encourage competition among students, sometimes still carried over at the college level. Students need to understand each other critically, objectively, and be skeptical of the issues discussed during online discussions. So the ability to collaborate becomes essential. Less experience in engaging in collaborative activities is the reason for the need for interactivity that respects all parties.

Tutor support aspects (TUT1, TUT2, TUT3, TUT4) are related to how lecturers play a role in supporting the success of participants' learning. The lecturer's position in education serves to ensure that all participants can be actively involved in the learning or training process. To obtain information and understand learning activities deeply, the lecturers directed the students to search from online learning sources and did not directly provide learning materials or information needed. This method seems to be quite successful in this online learning process. However, this aspect still needs to be improved, primarily related to the provision of appreciation and feedback by lecturers to students.

Support from fellow students (PEE1, PEE2, PEE3, PEE) for online learning occurred when other students provide support, respect, and empathy. Besides, in the learning process, students are expected to use positive words when discussing through forums or when chatting. During the lesson, this aspect was still quite good (scores above 3.00). The tendency to use positive language will be able to support other participants. There are always opportunities to increase in this aspect again. The results of observations and interviews with lecturers will support this analysis. A factor that might be a barrier to this aspect is the experience that students tend to experience lecturer-centered learning. So they still need to be developed in the ability to provide support to others in various forms.

The aspect of interpretation (INP1, INP2, INP3, INP4) measured the success of students and lecturers in understanding each other's communication. The lecturer's role in direct the learning activities so that all students are actively involved has an impact on the level of psychological pressure. A constructivist approach to learning makes excellent communication responsive. Responses to this aspect are relatively high (lowest 3.77 for INP2). This result is possible because students and lecturers tend not to have gaps regarding age and learning maturity.

\subsection{Effects of Demographics}

Considering the government's teaching and learning experience through MOEC, lecturers need to change the way they manage learning. Many factors determine their success. Some online learning constraints can arise, such as the support of decision-makers on campus, technology infrastructure, training, and other support [20]. Education in Eastern Indonesia also faces a similar problem [21]. However, the results of this study indicate that the lecturer in the Covid-19 mitigation period realized the importance of using technology in learning. Changes in teacher beliefs bring a new learning atmosphere in online learning [22-24]. Changes in teacher beliefs about the use of information and communication technology in learning are essential assets in online learning. Further support for lecturers is how lecturers can improve the process of social interaction in online learning. Findings related to the COLLES scores discussed earlier supports this analysis. Maintaining social interaction in online activities is an important issue [19,25].

Table 4 explains that it turns out that during current online learning, gender, fields of study, length of education, and time using social media do not affect their response to online learning as measured by COLLES. There are several explanations from other studies that gender does not affect online learning responses. There is a tendency that the current generation (millennial generation) tends to be the same between males and females in handling activities in cyberspace and online. This generation's characteristics that quickly adapt to new technologies also have an impact on the long-term use of social media. The influence of this technology that enters various sectors and even various scientific fields in a variety of forms of utilization make the field of study occupied by students does not affect the score of online learning responses.

\subsection{Learning Impacts}

WhatsApp has a variety of features that can be used as media to support the online lecture process. Lecturers utilized WhatsApp features in their learning process at various colleges in NTT include Documents (file sharing), Galleries (add photos, voice, and video), Chat (discussion), Voice Messaging and Video Call. Some of these features allow running various processes. Utilization of these features can increase social presence. There are some obstacles to learning, such as the internet access quality at home, the limited interaction between lecturers and students, and the response or feedback. Other studies show the same results that in online learning, the interaction of lecturers and students in various forms is significant [26-28].

Observations of existing activities on WhatsApp can provide an overview and a more profound explanation of 
the results of statistical analysis. In this study, online learning activities through WhatsApp are explored to discover the atmosphere of online learning. Some several features and events are used by lecturers to manage Relevance, Reflection, Interactivity, Tutor Support, Peer Support, and Interpretation. The use of various features such as dialogue activities will significantly affect online learning [29].

Figure 5 shows one of the activities used to grow these aspects. By providing problem-posing, students try to come up with ideas that the responses of other students in the form of answers will increase peer support and interactivity. Besides, this image shows the use of emoticons. Teachers and students may use emoticons in online activities aimed at making the real atmosphere awake. The forms of emoticons chosen can affect the level of self-reflection, support from others, and lecturers.

Figure 6 is another reflection of learning. Lecturer sent material in PDF format to be able to build the relevance of lectures. Students could download and learn, so they have knowledge when they are involved in discussions prepared by the lecturer.

In Figure 6, the lecturer provided a discussion room to be able to deepen the material. The discussion was prepared in several topics so that interaction can be structured between students. The provision of other learning resources also supports deep understanding. The impact of providing these resources supports the high relevance response discussed earlier. The interview with the two lecturers below shows that the lecturer has a particular strategy for achieving aspects of relevance.

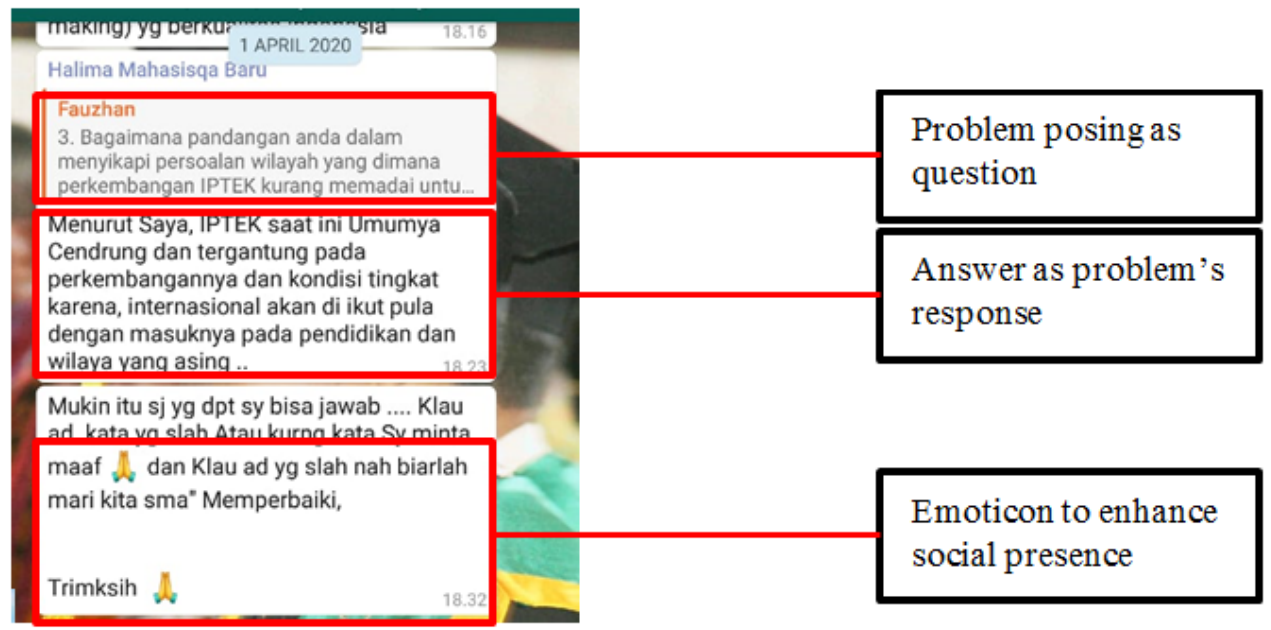

Figure 5. Discussion online activity

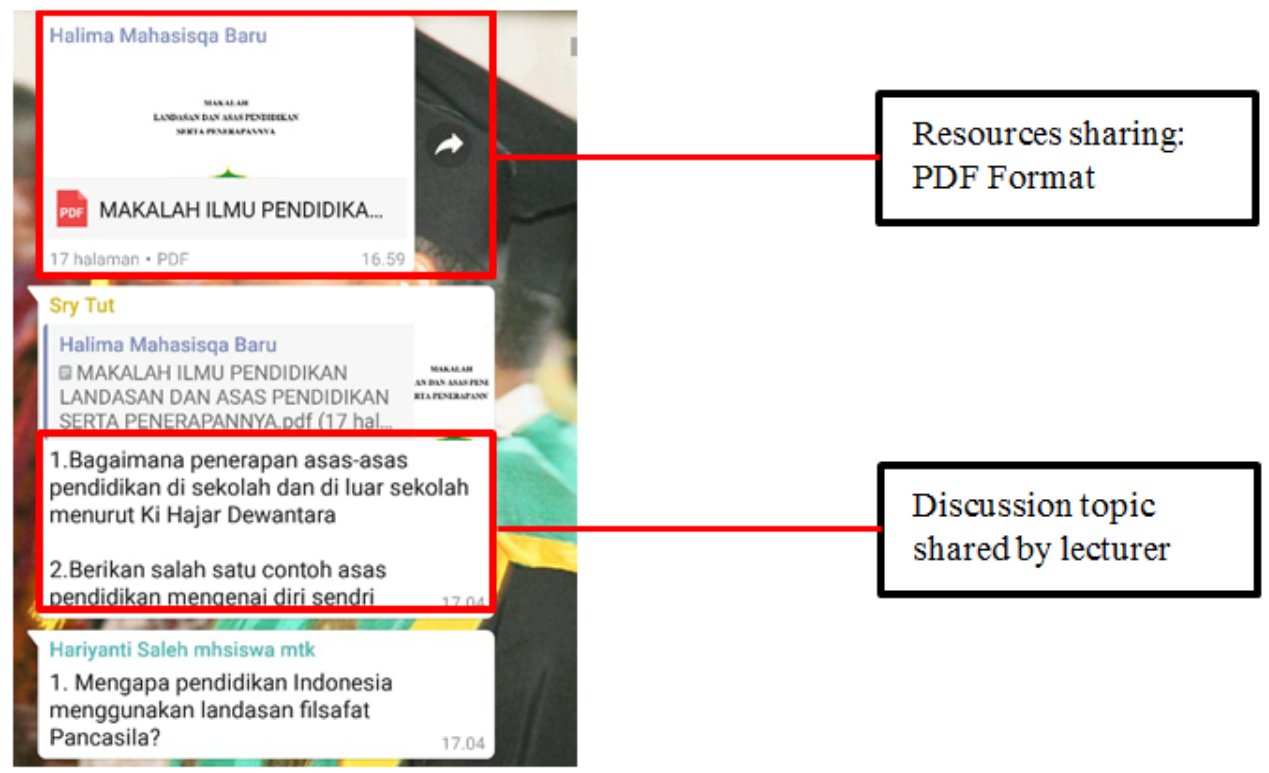

Figure 6. Resources sharing activity 
Lecturer 1: Karena Mata Kuliah sosial maka strateginya adalah presentasi makalah, tanya jawab antara mahasiswa. Dosen memantau dan sesekali memberi komentar, selain juga menugaskan dengan tugas rumah. Saya mengajar matakuliah sosial sehingga strategi yang saya gunakan adalah dengan presentasi, tanya jawab antar mahasiswa, dosen memberikan komentar, dan memberikan tugas rumah.

(Translation: Because social subjects, the strategy is the presentation of papers, questions and answers between students. The lecturer monitors and occasionally comments, as well as assigning homework. I teach social studies, so the strategies I use are with presentations, questions, and question and answers between students, lecturers give comments and homework.)

Lecturer 2: Grup WA, chat, voice note dan media seperti PPT maupun PDF. Karena yang paling mudah dijangkau oleh semua mahasiswa dalam grup. Hal ini disebabkan bila ingin melaksanakan diskusi dengan vitur video call tidak bisa mencakup seluruh mahasiswa yang tergabung dalam grup. Memberikan topik diskusi khusus kepada anak-anak. Setiap anak memperoleh satu topik sebagai topik utama dan berperan sebagai pembuka serta pemateri dalam diskusi tersebut.

(Translation: WA groups, chat, voice notes, and media such as PPT and PDF. Because the most accessible to all who are in the group. This situation is because if we want to carry out discussions with the video call feature, it cannot include all students who are members of the group. I provide specific discussion topics to students. Each student gets one problem as the main topic and acts as an opener and speaker in the discussion.)

As explained previously, appreciation and encouragement from lecturers on students greatly influence the success of online learning. Figure 7 shows some of the lecturers' efforts to improve interpretation and support tutors in the form of praise for their participation in quizzes and feedback with emoticons. Tutor support and great interpretation expressed some of these activities in resonance.

From the study, both statistically and observations on online activities on WhatsApp, it can be explained the success rate of online learning through student responses. From the analysis of each presented aspect, in overall online learning with WhatsApp provides opportunities for optimum learning success. Other researchers also found that social media (WhatsApp) can constructively encourage good relations between community members $[30,31]$. The factors that might make online learning obstacles are experience factors that students tend to experience teacher-centered learning, rarely deal with open problems (ill-defined problems), and rarely involved in collaborative learning.

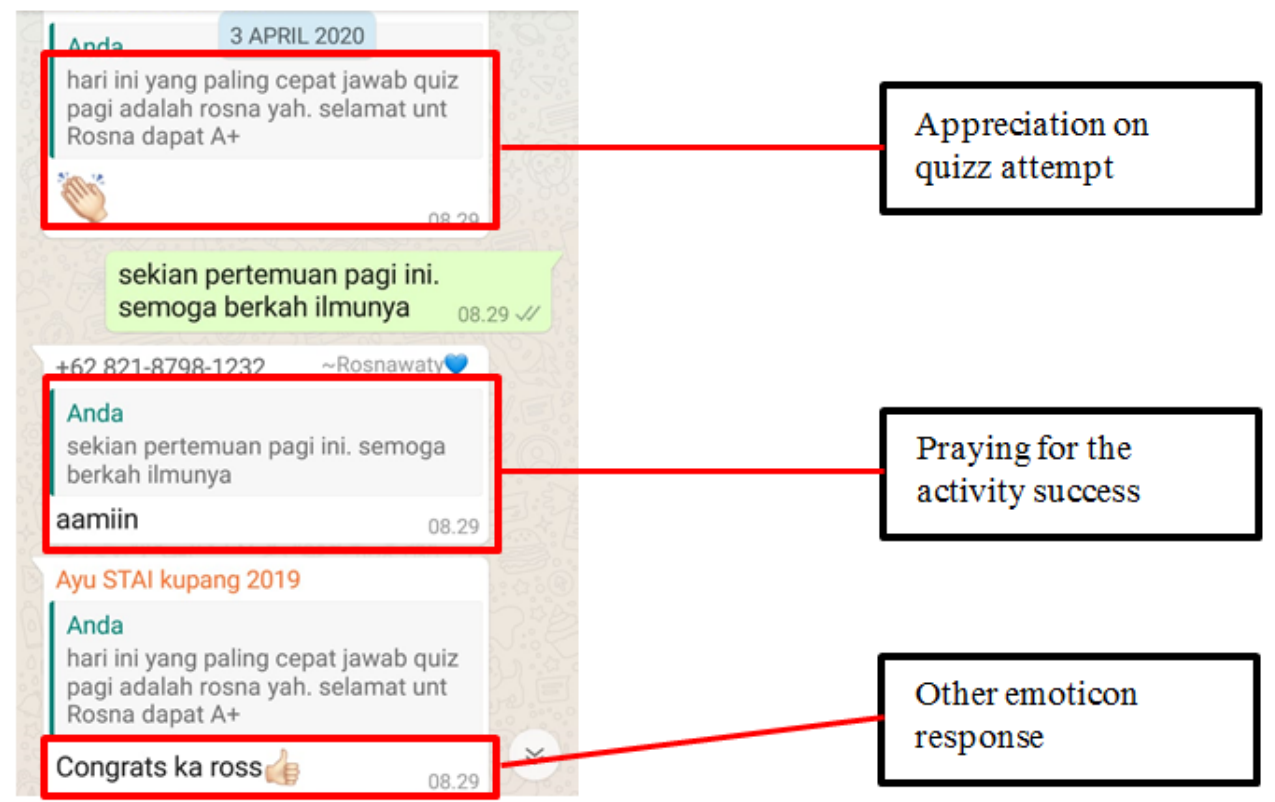

Figure 7. Feedback and appreciation activity 
The results of previous studies indicate that learning with WhatsApp can support the increase in student attitudes and attitudes compared to learning in class [32-34]. The learning experience through online learning with WhatsApp is perceived by students in six aspects, namely relevance, reflective thinking, interactivity, tutor support, peer support, and interpretation. Orientation on strengthening critical thinking skills, communication, creativity, and collaboration can be well facilitated through online learning, although teachers can implement several strategies to improve learning performance. This result is an optimistic hope for the subsequent application of online learning. As millennials who are very comfortable with online virtual activities, students become an essential factor in the success of online learning $[12,18,35]$. Things that need attention to further development is how to increase interactions between students who are more fun without being trapped in just to fulfill learning obligations or known as social presence. The role of lecturers is significant in the management of this learning. Lecturers who use sudden online learning in anticipation of Covid-19 need to be improved from a pedagogical point of view when implementing online learning. The essential ability to design online learning determines the success of that learning $[30,31,36]$. Social media platforms such as WhatsApp are increasingly being used in formal education. Research, training that facilitates educators on how to manage productive learning communities on social media platforms needs to be developed [7,23,36,37].

\section{Conclusions}

Although there are some negative factors that are feared about the use of social media, but it cannot be denied that this media also provides various opportunities in building community in the modern era, including in the field of education. In the six aspects of constructivist success as measured by COLLES, it shows that students feel their needs are fulfilled. In all these aspects, students tend to give good or even excellent responses. Demographic variables (gender, the field of study, length of education, and experience using social media) did not influence student responses. Students of almost the same age indicate that they are from the millennial generation who are very literate in the use of this technology. So that the impact does not appear the influence of these variables, the interaction seen in the posts in WhatsApp shows that lecturers and students at a certain level have tried to interact with each other as best they can. However, this sudden online learning is still very likely to be successful. The role of education policy-makers is to provide lecturers with opportunities to improve the level of social presence in online lectures.

\section{Acknowledgements}

Institute of Research and Community Service of Ahmad Dahlan University.

\section{REFERENCES}

[1] A.M. Schwartz, J.M. Wilson, S.D. Boden, T.J. Moore Jr, T.L. Bradbury Jr, N.D. Fletcher Managing resident workforce and education during the COVID-19 pandemic: Evolving strategies and lessons learned. JBJS Open Access, Vol.5, No.2, e0045, 2020.

[2] G. Basilaia, D. Kvavadze. Transition to online education in schools during a SARS-CoV-2 Coronavirus (COVID-19) pandemic in Georgia. Pedagogical Research, Vol.5, No.4, $1-9,2020$.

[3] S. Burgess, H. H. Sievertsen. Schools, skills, and learning: The impact of COVID-19 on education. VoxEu. Org, Online available from https://voxeu.org/article/impact-covid-19-ed ucation.

[4] R.M. Viner, S.J. Russell, H. Croker, J. Packer, J. Ward, C. Stansfield, O. Mytton, C. Bonell, R. Booy. School closure and management practices during coronavirus outbreaks including COVID-19: a rapid systematic review. The Lancet Child \& Adolescent Health, USA, 2020.

[5] Circular Letter of MOEC. Pembelajaran secara Daring dan Bekerja dari Rumah untuk Mencegah Penyebaran Covid-19. Online available from https://www.kemdikbud.go.id

[6] N.A. Zulkanain, S. Miskon, N.S. Abdullah. An adapted pedagogical framework in utilizing WhatsApp for learning purpose. Education and Information Technologies, Vol.1, $1-12,2020$.

[7] C. Barhoumi. The Effectiveness of WhatsApp Mobile Learning Activities Guided by Activity Theory on Students' Knowledge Management. Contemporary Educational Technology, Vol.6, No.3, 221-238, 2015.

[8] L.Y. Muilenburg, Z.L. Berge. Student barriers to online learning: A factor analytic study. Distance education, Vol. 26, No.1, 29-48, 2005.

[9] E. Vayre, A.M. Vonthron. Psychological engagement of students in distance and online learning: Effects of self-efficacy and psychosocial processes. Journal of Educational Computing Research, Vol.55, No.2, 197-218, 2017.

[10] K. Aesaert, J. Voogt, E. Kuiper, J. van Braak. Accuracy and bias of ICT self-efficacy: An empirical study into students' over-and underestimation of their ICT competences. Computers in Human Behavior,Vol.75, 92-102, 2017.

[11] W. Zhang, Y. Wang, L. Yang, C. Wang. Suspending classes without stopping learning: China's education emergency management policy in the COVID-19 outbreak. Journal of Risk Financial Management, Vol.13, No.3, 55, 2020.

[12] D. Bouhnik, M. Deshen, R. Gan. WhatsApp goes to school: Mobile instant messaging between teachers and students. Journal of Information Technology Education: Research, 
Vol.13, No.1, 217-231, 2014.

[13] C. Kim, M.K. Kim, C. Lee, J.M. Spector, K. DeMeester. Teacher beliefs and technology integration. Teaching and teacher education, Vol.29, 76-85, 2013.

[14] P.S. Hsu. Examining current beliefs, practices and barriers about technology integration: A case study. TechTrends, Vol.60, No.1, 30-40, 2016.

[15] H. Uzunboylu, F. Ozdamli. Teacher perception for mlearning: scale development and teachers' perceptions. Journal of Computer assisted learning, Vol.27, No.6, 544-556, 2011.

[16] D. Sulisworo, P.S. Rohmadheny, N. Fatimah, D.B. Arif, M.F. Saifuddin. Learning analytics to predict student achievement in online learning during Covid19 mitigation. International Journal of Psychosocial Rehabilitation, Vol.24, No.10, 1844-1861, 2020.

[17] J.E. Hughes. Descriptive indicators of future teachers' technology integration in the PK-12 classroom: Trends from a laptop-infused teacher education program. Journal of Educational Computing Research, Vol.48, No.4, 491-516, 2013.

[18] S.K. Howard, A. Chan, P. Caputi. More than beliefs: Subject areas and teachers' integration of laptops in secondary teaching. British Journal of Educational Technology, Vol.46, No.2, 360-369, 2015.

[19] K. McKnight, K. O'Malley, R. Ruzic, M.K. Horsley, J.J. Franey, K. Bassett. Teaching in a digital age: How educators use technology to improve student learning. Journal of research on technology in education, Vol.48, No.3, 194-211, 2016.

[20] P.A. Ertmer, A. Ottenbreit-Leftwich. Removing obstacles to the pedagogical changes required by Jonassen's vision of authentic technology-enabled learning. Computers \& Education, Vol.64, 175-182, 2013.

[21] D. Sulisworo, N. Fatimah, M.J. Susilo. Predicting students' achievement during COVID-19 mitigation through self-regulated learning profiles: Indonesian context. TEST, Vol.23, 8902-8913, 2020.

[22] B.W. O'bannon, K. Thomas. Teacher perceptions of using mobile phones in the classroom: Age matters!. Computers \& Education, Vol.74, 15-25, 2014.

[23] J. Voogt G. Knezek, M. Cox, D. Knezek, A. Brummelhuis. Under which conditions does ICT have a positive effect on teaching and learning? A Call to Action. Journal of computer assisted learning, Vol.29, No.1, 4-14, 2013.

[24] A.P. Rehmat, J.M. Bailey. Technology integration in a science classroom: Preservice teachers' perceptions. Journal of Science Education and Technology, Vol.23, No.6, 744-755, 2014.
[25] D. Ruggiero, C.J. Mong. The teacher technology integration experience: Practice and reflection in the classroom. Journal of Information Technology Education, Vol.14, 161-178, 2015.

[26] D. Baishya, S. Maheshwari. WhatsApp groups in academic context: Exploring the academic uses of whatsapp groups among the students. Contemporary Educational Technology, Vol.11, No.1, 31-46, 2020.

[27] S. Soria, M. Gutiérrez-Colón, A.D. Frumuselu. Feedback and mobile instant messaging: Using whatsapp as a feedback tool in EFL. International Journal of Instruction, Vol.13, No.1, 797-812, 2020.

[28] I. Ketut Suardika, Alberth, Mursalim, Siam, L. Suhartini, P. Nikolaus. Using WhatsApp for teaching a course on the education profession: Presence, community and learning. International Journal of Mobile and Blended Learning, Vol.12, No.1, 17-32, 2020.

[29] K. König. Sequential patterns in SMS and WhatsApp dialogues: Practices for coordinating actions and managing topics. Discourse and Communication, Vol.13, No.6, 612-629, 2019.

[30] S.R. Agrawal, D. Mittal. Constructive usage of WhatsApp in education sector for strengthening relations. International Journal of Educational Management, Vol.33, No.5, 954-964, 2019.

[31] H.Mulyono, D.R. Amalia, G. Suryoputro. Politeness strategies in teacher-student whatsapp communication. PASAA, Vol.58, 295-318, 2019.

[32] A.B. Amry. The impact of WhatsApp mobile social learning on the achievement and attitudes of female students compared with face to face learning in the classroom, European Scientific Journal, Vol.10, No.22, 116-136, 2014.

[33] T. Bansal, D. Joshi. A study of students' experiences of mobile learning. Global Journal of Human Social Science, Vol.14, No.4, 26-33, 2014.

[34] S. Gon, A. Rawekar. Effectivity of e-learning through WhatsApp as a teaching learning tool. MVP Journal of Medical Science, Vol.4, No.1, 19-25, 2017.

[35] M.M. Abualrob, S. Nazzal. Using whatsapp in teaching chemistry and biology to tenth graders. Contemporary Educational Technology, Vol.11, No.1, 55-76, 2020.

[36] A. Campbell. Design-based research principles for successful peer tutoring on social media. International Journal of Mathematical Education in Science and Technology, Vol.50, No.7, 1024-1036, 2019.

[37] B. Urien, A. Erro-Garcés, A. Osca. WhatsApp usefulness as a communication tool in an educational context. Education and Information Technologies, Vol.24, No.4, 2585-2602, 2019. 